Short Communication

\title{
REPORT ON A HERONRY AT THE RAJSHAHI UNIVERSITY CAMPUS
}

\author{
A. M. Saleh Reza, Mosharrof Hossain and Selina Parween* \\ Department of Zoology, University of Rajshahi, Rajshahi 6205, Bangladesh \\ *Corresponding author; email: selina.parween@yahoo.com
}

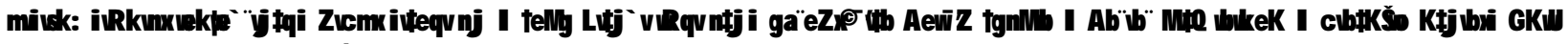

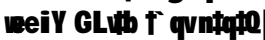

Key words: Heronry, cormorant, heron, egret, RU campus

Heronry refers to a nesting congregation of colonial aquatic birds belonging to the family Ardeidae which comprises herons and egrets (Ali 1996). Ray et al. (1996), however, defined heronry as the nesting areas of herons, egrets and other associated water birds. Heronries may be composed of a single or mixed species of water birds, which have significant importance not only to ornithologists, biologists and bird watchers, but also to amateur photographers, reporters and tourists. Such heronries are located around the world viz. Kaggaladu Heronry in Karnataka, India, Cleeve Heronry in North Somerset, UK, Hilgay Heronry in Fens, UK and The Florida Everglades in Florida, USA, and have become important tourist spots (Anon. 2004). Zoologists, ecologists and ornithologists work for the conservation and management of heronries by protecting the nesting and foraging grounds of the aquatic bird species (Anon. 2004). Subramanya (2005) reported on the heronries of Tamil Nadu, India.

Natural heronries are present in different places of Bangladesh, but detailed descriptions of such heronries are lacking. However, a large heronry in Bangladesh has been reported by Khan (2006), which is present at the Pachamaria village of Shilmaria Union at Puthia Upazilla, Rajshahi District. Age of this heronry is more than 10 years (Khan, 2006, Islam et al. 2009), and the authors reported it as the possible largest one in Bangladesh outside the government reserve forests of the Sunderbans, Sylhet, Chittagong and Mymensingh. Here we report a new heronry located at the Rajshahi University (RU) Campus.

A research project entitled 'In situ conservation of birds at Rajshahi University Campus' (funded by the University Grants Commission/RU) is going on. The project team is working since 2006, maintaining a more or less daily routine of bird watching at the RU Campus, and collecting data on the habitat, nest and behaviour of the birds. Bird watching is done at random from dawn to dusk, photographing the birds and their habitats whenever possible. Various aspects of the present heronry are described in the following paragraphs.
Nesting site: The heronry is located at the south-east corner of the Taposhi Rabeya Hall, adjacent to the Begum Khaleda Zia Hall, both being female students' halls of residence (Map 1). There are about 40 trees, each about 30-35 ft high, inside the walled territory of the halls. The birds made their nests on these trees at an average height of 20-30 ft. Outside the boundary wall in the east, there is a man-made water body just few metres away from the trees. A medium-sized pond is also present in between the halls. A large pond, a cropland and open wild grassland are present nearby the heronry which is guarded by fence (Plate 1).

Flora and fauna: Mahogany (Swietenia mahagoni), mango (Magnifera indica), Babla (Acacia sp.) and coconut (Cocos nucifera) constitute the predominant trees of the heronry. Almost $90 \%$ of the birds reside on Mahogany tree. In the open grassland around the heronry there are a few species of grass and other plants like Kochu (Calocasia sp.), Kanshira (Commelina sp.), Kata khuria (Amaranthus spinusus), Bathua (Chenopodium album), Shial muthi (Veronia sp.), Lajjabati (Mimosa sp.) and Thankuni (Centella asiatica). Paddy and Dhancha (cork bean) are usual crops. Hydrophytes like Helencha (Enhydra sp.), Kalmi (Ipomea sp.), water hyacinth (Eichornia crassipes) and Duck weed (Lemna minor) are the common flora of this area.

Fauna of the site includes a number of insects (e.g., few species of dragon flies and damsel flies, few coleopterans, two species of hemipterans, three species of ants, eight species of butterflies, grasshoppers, crickets, stick insect) which commonly inhabit the grassland, cropland and adjacent to the ponds or small water bodies. There are a large number of castings of annelids, two species of millipedes, two to three species of freshwater snails and mussels. Among the vertebrates, there are frogs (Rana tigrina) during rainy season (Rana tigrina), lizards (Calotes sp.), rats (Rattus rattus), squirrels (Funambulus sp.), and different 
species of birds (Table 1). In addition, a large number of crows share the same abode along with the water birds. The crows mainly aggregate around the water birds to feed on the food droplets of the water birds, and occasionally prey on the broods of the latter. Moreover, the exotic carp species which are cultured in the adjacent water bodies constitute another important group of the fauna.

Species composition: The heronry did not exist even during 2008, though a number of water birds were found foraging by the ponds and ditches present at the RU campus. So the age of the heronry appears to be a little bit more than a year. A small colony of four pairs of adult Great/large Cormorants, Night herons with five fledges, and Little egrets was established first, which started to evolve as heronry in early 2009. Gradually the population of the colony, especially the Night herons and the cormorants, has increased since then. The number of nests of each species and the number of nest per tree have not been confirmed yet, but from the number of adults it is estimated that at least there are 40 nests of the cormorants and 25-27 nests of the Night herons. The major nesting species of the heronry is the Night heron (Nycticorax nycticorax) which live in association with the Great Cormorant, the Pond heron and the Little egret (Table 2, Plate 2).

Table 1. Avifauna of the heronry at the RU Campus

\begin{tabular}{|c|c|c|c|}
\hline Families & Scientific names & English names & Bangla names \\
\hline \multirow{2}{*}{$\begin{array}{l}\text { Pycnonotidae } \\
\text { (Bulbuls) }\end{array}$} & Pycnonotus jocosus (Linnaeus 1758) & Red Whiskered Bulbul & Sipahi Bulbul (IUCN) \\
\hline & $\begin{array}{l}\text { Pycnonotus caferSub sp. bengalensis } \\
\text { (Linnaeus 1766) }\end{array}$ & Red Vented Bulbul & $\begin{array}{l}\text { Bangla Bulbul IUCN)/Kalo } \\
\text { Bulbul }\end{array}$ \\
\hline \multirow{2}{*}{$\begin{array}{l}\text { Meropidae } \\
\text { (Bee-eaters) }\end{array}$} & Merops orientalis Latham 1802 & Green Bee-eater & Shobuj Suichora, Banspata \\
\hline & $\begin{array}{l}\text { Merops philippinus } \\
\text { (Linnaeus 1766) }\end{array}$ & Blue tailed Bee-eater & Neellej Suichora \\
\hline \multirow{3}{*}{$\begin{array}{l}\text { Alcedinidae } \\
\text { (Kingfishers) }\end{array}$} & Alcedo meninting Horsefield 1821 & $\begin{array}{l}\text { Common Kingfisher/ } \\
\text { Blue-eared Kingfisher }\end{array}$ & Patimachranga \\
\hline & $\begin{array}{l}\text { Halcyon smyrnensis } \\
\text { (Linnaeus 1758) }\end{array}$ & White-throated Kingfisher & Sadagola Machranga \\
\hline & Halcyon capensis (Linnaeus 1758) & Stork-Billed Kingfisher & Meghau \\
\hline Rallidae & $\begin{array}{l}\text { Amaurornis phoenicurus (Pennant } \\
\text { 1769) }\end{array}$ & White-breasted Waterhen & Dahuk \\
\hline $\begin{array}{l}\text { Columbidae } \\
\text { ( Doves) }\end{array}$ & Streptopelia chinensis (Scopoli 1786) & Spotted Dove & $\begin{array}{l}\text { Teela ghughu, } \\
\text { Teelima ghughu }\end{array}$ \\
\hline \multirow{2}{*}{$\begin{array}{l}\text { Picidae } \\
\text { (Woodpeckers) }\end{array}$} & Dryocopus javanense (Ljungh, 1797) & Greater Flameback & Kaththokra \\
\hline & Dendrocopos macei (Vieillot, 1818) & $\begin{array}{l}\text { Stripe-breasted } \\
\text { woodpecker }\end{array}$ & Kaththokra \\
\hline \multirow{4}{*}{$\begin{array}{l}\text { Sturnidae } \\
\text { (Starlings) }\end{array}$} & Acridotheres tristis (Linnaeus 1766) & Common Myna & Bhat Shalik (IUCN) \\
\hline & Acridotheres fuscus (Wagler 1827) & $\begin{array}{l}\text { White-vented Myna/ } \\
\text { Jungle Myna }\end{array}$ & Jhunti Shalik (IUCN) \\
\hline & Sturnus contra (Linnaeus 1758) & $\begin{array}{l}\text { Indian Pied Starling/Asian } \\
\text { Pied Starling }\end{array}$ & Gubre Shalik/ Pakra Shalik \\
\hline & Sturnus pagodarum (Gmelin 1789) & Brahminy Starling & $\begin{array}{l}\text { Bamon Shalik } \\
\text { (IUCN) }\end{array}$ \\
\hline Muscicapidae & Copsychus saularis (Linnaeus 1758) & Oriental Magpie Robin & Doel (IUCN) \\
\hline \multirow[t]{2}{*}{$\begin{array}{l}\text { Ardeidae } \\
\text { (Herons and Egrets) }\end{array}$} & Ardea cinnamomea Gmelin 1789 & $\begin{array}{l}\text { Cinnamon Bittern/ } \\
\text { Chestnut Bittern }\end{array}$ & Lal Bok/Khoira Bok \\
\hline & Bubulcus ibis Linnaeus 1758 & Cattle Egret & Go Bok (IUCN) \\
\hline Corvidae & $\begin{array}{l}\text { Corvus splendens } \\
\text { (Vieillot 1817) }\end{array}$ & House Crow & Pati Kak \\
\hline
\end{tabular}


Table 2. Major birds of the heronry at the RU Campus

\begin{tabular}{|l|l|l|l|}
\hline Families & Scientific names & English names & Bengali names \\
\hline $\begin{array}{l}\text { Phalacrocoracidae } \\
\text { (Cormorants) }\end{array}$ & $\begin{array}{l}\text { Phalacrocorax carbo } \\
\text { (Linnaeus 1758) }\end{array}$ & $\begin{array}{l}\text { Great /Large } \\
\text { Cormorant }\end{array}$ & Boro Pankouri \\
\hline \multirow{5}{*}{$\begin{array}{l}\text { Ardeidae } \\
\text { (Herons and Egrets) }\end{array}$} & $\begin{array}{l}\text { Nycticorax nycticorax } \\
\text { (Linnaeus 1758) }\end{array}$ & $\begin{array}{l}\text { Black Crowned } \\
\text { Night Heron }\end{array}$ & $\begin{array}{l}\text { Nishi Bok/Waak } \\
\text { (IUCN) }\end{array}$ \\
\cline { 2 - 4 } & Ardeola grayii Sykes 1832 & Indian Pond Heron & $\begin{array}{l}\text { Kana Bok/Kani Bok, } \\
\text { Korchet Bok (IUCN) }\end{array}$ \\
\cline { 2 - 4 } & $\begin{array}{l}\text { Egretta egarzetta } \\
\text { (Linnaeus 1758) }\end{array}$ & Little Egret & Choto Bok (IUCN) \\
\hline $\begin{array}{l}\text { Strigidae } \\
\text { (Owls) }\end{array}$ & $\begin{array}{l}\text { Ketupa zeylonensis } \\
\text { Gmelin 1788 }\end{array}$ & Brown fish Owl & $\begin{array}{l}\text { Khoira Mechho- } \\
\text { Pencha (IUCN) }\end{array}$ \\
\hline
\end{tabular}

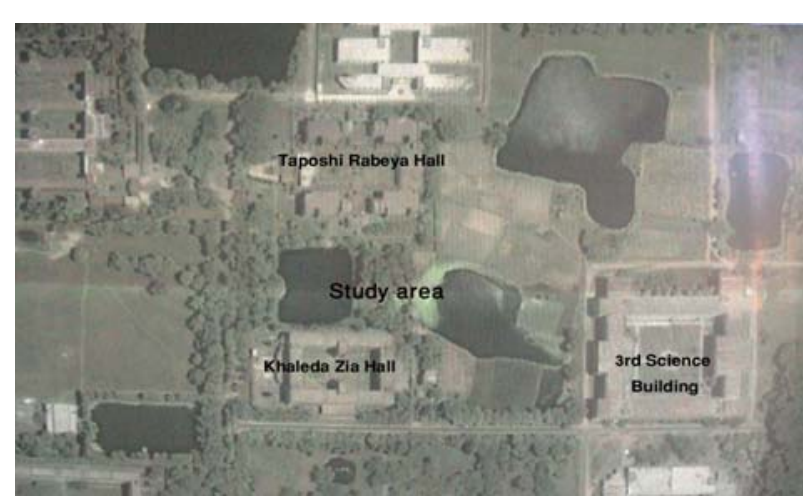

Map 1. GIS map of the study area (source: Google Earth)

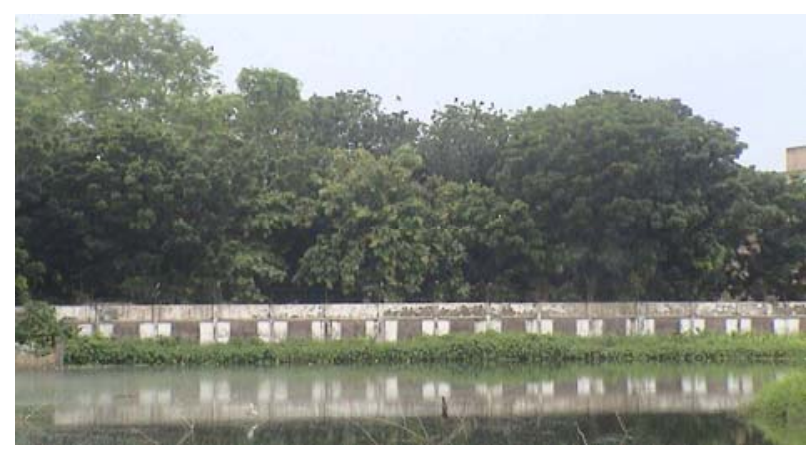

Plate 1. Heronry site

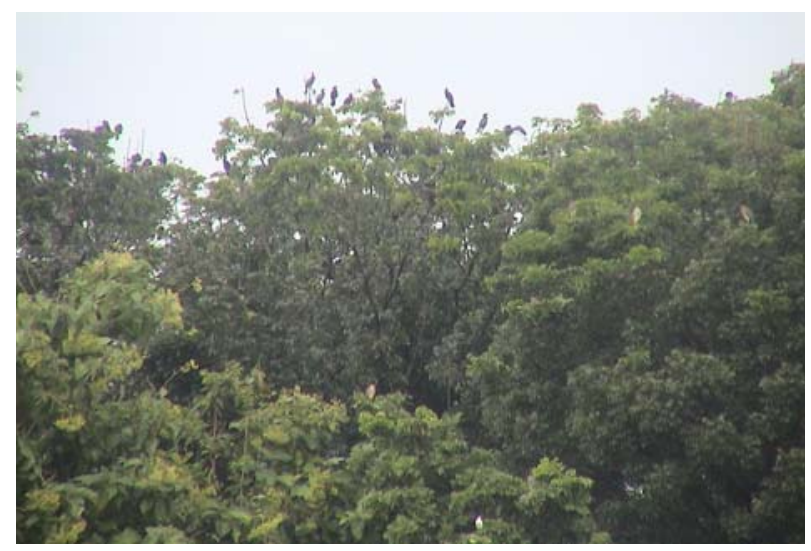

Plate 2. Heronry proper at the RU campus
As observed and recorded on 7 and 9 August 2010, the number of adult Night herons was around 20-22 pairs and that of fledges (juveniles) was nearly 50 . The number of other species of birds residing in the heronry is not confirmed yet, although there might be 25-28 pairs of adult Cormorants. Three species of egrets along with the little blue herons built a large colony in the Grand Lake heronry (Stancil et al. 1988). While Narayan et al. (2006) reported a heronry from Kerala, India, which was a mixed species colony, composed of species like the Great cormorant, Darter (Snake bird), Open-billed stork along with the major habitant the Grey heron. The Pachamaria heronry is also reported to be a mixed species heronry comprising 10 Darters (globally threatened), 200 Asian Openbill stork, 50 Great Cormorants as the permanent inhabitant, 50 Black crowned Night herons, 30 Little egrets, 20 Little cormorants and 50 Cattle egrets (Khan 2006, Islam et al. 2009). The heronries of Tamil Nadu have more or less similar species composition like the Pachamaria. Subramanya (2005) observed that the Night heron and the Indian Cormorant live together with Eurasian Spoonbill, Asian Openbill Stork, Grey heron, Large Egret, Cattle Egret and Oriental White Ibis.

Foraging area: The cormorants, the little egrets and the pond herons use to forage at the ponds situated nearby the heronry. Whereas, the Night herons use to fly in flocks from dusk to dawn, about two km away from the RU campus to the river Padma to feed. Fledges of the Night herons are seldom found to feed in the adjacent water bodies during day time, when there is no human working in the cropland. Kushlan (2000) reported that foraging areas of herons and egrets may range from a few to several $\mathrm{km}$ from the heronry and frequent shifting of the foraging area may occur.

Future of the heronry: Literature show that heronries are not long lasting. Permanent abandonment is the final part of a heronry's cycle, and may occur as a gradual decline or even as a sudden absence after many years of successful habitation. Baker (2007) pointed out a few 
important reasons for abandonment of a heronry such as: i) repeated predation of nests by predators other than man, ii) loss of habitat due to guanotrophy, iii) human disturbance, and iv) hostile attitude of man towards the birds. Moreover, herons and egrets are luxury food items of man, who cause mass destruction of heronries. Large heronries are often considered as nuisance when these are located adjacent to the residential areas. These might pose a number of inconveniences because of their noise, fouling odour of the excreta, decomposing bodies, broken eggs, associated insect parasites, and a potential danger to the aircrafts (Ray et al. 1996).

Conservation of the heronry: The major conservation measures that can be taken to save the present heronry are: i) protection of the nesting site from any disturbance, ii) protection of the habitat and the foraging areas, and iii) reducing human activities around the sites. In addition, community advocacy about the significance of heronry and its importance in biodiversity and ecological balance can play major role in its conservation. People of the village Pachamaria, for example, conserved the heronry successfully through the Community Conserved Area (CCA) programme, which made the village an interesting place for the visitors (Islam et al. 2009).

Acknowledgements: The authors are thankful to the Rajshahi University for providing a one-year grant from the UGC (University Grants Commission). Mr. Md. Ariful Hasan, Assistant Professor, Department of Zoology, RU, deserves special mention for his valuable time spent with the project team during the present survey.

\section{References}

Ali S. 1996. The Book of Indian Birds. Bombay Natural History Society, Oxford University Press, Bombay.

Anonymous 2004. A summary of Great Blue Heron nesting activity. Stanley Park Heronry Monitoring Report, Stanley Park Ecological Society. 4 pp.

Baker KC. 2007. Management Plan for Potomac Creek Heronry. Paper submitted for the Degree of Master of Natural Resources, Falls Church, Virginia, USA. 93 pp.

Islam MA, Marinova D, Khan MH, Wahidunnessa G, Chakma S, Uddin M, Jahan I, Akter R, Mohsanin S and Tennant E. 2009. Community Conserved Areas (CCAs) in Bangladesh. Wildlife Trust of Bangladesh. $76 \mathrm{pp}$.

Khan R. 2006. 700 species of birds in Bangladesh-half are migratory. Holiday, August 18, 2006.

Kushlan JA. 2000. Heron feeding habitat conservation. In: Heron Conservation (JA Kushlan and H. Hafner eds.) pp 219-235. Academic Press, San Diego, CA.

Narayan SP, Raju DV, Unnikrishnan N, Vasan S and Sreekumar B. 2006. Do Great Cormorants Phalacrocorax carbo displace other colonial birds at Kumarakom heronry (Kerala)? Indian Birds 2(5): 138.

Ray C, Telfair II, Thompson BC and Tschirhart L. 1996. Nuisance Heronries in Texas. Characteristics and Management $\left(2^{\text {nd }}\right.$ edn). Texas Wildlife Damage Management Service, Texas A \& M Univ. Syst. 16 pp.

Stancil JW, Rakevitz RF and Lesslie Jr, DM. 1988. Species composition of a mixed ardeid colony on Grand Lake, Oklahoma. Proc. Okla. Acad. Sci. 68: 69-70.

Subramanya, S. 2005. Heronries of Tamil Nadu. Indian Birds 1(6): $126-140$.

Manuscript received on 18 October 2010 and revised on 9 January 2011 